Received 21.03.2017 Reviewed 08.06.2017 Accepted 23.06.2017

A - study design

B - data collection

C - statistical analysis

D - data interpretation

E - manuscript preparation

F - literature search

\section{The quality of surface waters of the dam reservoir Mexa, Northeast of Algeria}

\author{
Sofia BAHROUN ${ }^{1)}$ ABCDEF $\bowtie$, Warda CHAIB ${ }^{2)}$ ABCDEF
}

\author{
1) Badji Mokhtar University, Department of Geology, Annaba BP12, 23000, Algeria; e-mail: sofia bah@yahoo.fr \\ ${ }^{2)}$ Centre of Scientific and Technical Research in the Dry Areas (CRSTRA), Biskra, Algeria; e-mail: wardalita1@yahoo.fr
}

For citation: Bahroun S., Chaib W. 2017. The quality of surface waters of the dam reservoir Mexa, Northeast of Algeria. Journal of Water and Land Development. No. 34 p. 11-19. DOI: 10.1515/jwld-2017-0034.

\begin{abstract}
In this work, we have conducted a physicochemical study that assesses the impact of agricultural activities and urban domestic wastewater on the surface water quality of the dam reservoir Mexa in the area of El-Taref, which is located in the eastern coastal basin of Constantine. 36 samplings have been conducted for three years (2010, 2011 and 2012), at the rate of one sampling per month on the dam reservoir water; 36 samples have been analysed. The samples taken have been subjected to an in situ measurement of physicochemical parameters (temperature, hydrogen potential, electric conductivity and dissolved oxygen) and laboratory analysis (anions, cations, biological oxygen demand, chemical oxygen demand, organic matter, phosphate, nitrate, nitrite and ammonium).

Concentrations of various organic and inorganic pollutants varied from one month to another and from one year to another. From a temporal point of view, the contamination of water of the dam reservoir Mexa varies according to climatic conditions, being generally low during the winter period and high during the low-flow periods. The results obtained reveal that water of the dam reservoir Mexa is fairly contaminated. It is certain that the dam reservoir is subject to pollution of agricultural and urban origin.
\end{abstract}

Key words: dam reservoir Mexa, organic compounds, pollution, water quality

\section{INTRODUCTION}

Water resource protection is one of the most essential concerns of any environmental policy [ATTOUI et al. 2016]; water becomes a global strategic issue whose management must essentially integrate into a sustainable development policy perspective [ALLALGUA et al. 2014]. In fact, some assert that it will be a war issue, in the third millennium, as it is the case for oil in the past and today [GARCIA 2006]. The competition between agriculture, industry and drinking water supply for access to limited existing water requires development efforts of many countries [REMINI 2010].

Dams provide many benefits for our society such as the supply of drinking and irrigation water [Derdous et al. 2015]. The dam Mexa is one of the structures for the mobilization of surface water. It was constructed to ensure the protection of downstream areas from flooding and to supply drinking water to the provinces of El-Taref and Annaba. This dam reservoir receives, among others, the surface water from certain wadis that include urban effluents. The main problem of the dam reservoir water is contamination by organic compounds from domestic wastewater from agglomerations, engendering the degradation of the water quality. They may contain significant quantities of natural organic matter such as humic substances, as well as organic compounds derived from various pollutants or intensive agricultural practices [ACHOUR 2001].

Given the demographic growth of the city of El-Taref and the deterioration of the quality of these 
waters, this dam could alleviate this problem of water [ABHCSM 2005]. In order to meet the needs of the population, a study of characterization and assessment of the dam reservoir water quality is necessary. As current knowledge suggests, work has been carried out on the dam reservoir water quality by Agency Hydrographic Basin (Fr. Agence de Bassin Hydrographique) [ABHCSM 2005; HARRAT, ACHOUR 2010] on the physicochemical quality of surface waters by the determination of mineral and organic parameters, and the present work, which aims to characterize the waters of this dam for the period from January 2010 to December 2012, comes within this framework.

\section{PRESENTATION OF THE STUDY AREA}

Dam Mexa is located at the extreme Northeast of Algeria (Fig. 1), on the eastern Wadi Kebir, $20 \mathrm{~km}$ south of the town of El Kala, and has been put into service in 1998. This dam reservoir has initially covered a basin of an area of $560 \mathrm{~km}^{2}$, reduced to $393 \mathrm{~km}^{2}$ after the construction of a dam on Wadi Barbara in Tunisia and reduced to $158 \mathrm{~km}^{2}$ after the construction of the dam Bougous. This work regularizes an annual volume of $30 \mathrm{hm}^{3}$ for the supply of drinking water to the corridor of El Kala - Annaba [Ministère des Ressources en Eau 2009]. The study area is subject to a temperate climate characterized by two seasons, the first is wet from September to May, and the second is dry from May to September [BAHROUN et al. 2016].

From a geological point of view, the study area is part of the geological domain of the Algerian north -eastern Tell [VILLA 1980]. This domain extends from the region of Constantine to the Algerian-Tunisian border. The basin of Mafragh (Bounamoussa and eastern Kebir) includes the following units:

- Triassic located south of the study area (Triassic diapirs, vermicular limestone, set of pelitic sandstones);

- the sedimentary terrains of Oligocene to lower Burdigalian; these are sandstones, clays and marls;
- some deposits of Quaternary are of marine origin (alluvial deposits, beach sandstone), and others are part of continental sedimentation (sandstone, red soil, dunes, screes, and alluvia) [DERRADJI et al. 2007].

Available statistics announce 373183 inhabitants for the whole basin, estimate 2011, according to Census 2008. This population is highly concentrated in the most important areas such as, El-Taref and El Kala whose rate of urbanization recorded in different localities has showed a slide of the dispersed and rural population toward important groups located on road axes [BRAhamia, SEMOUK 2010]. The region has undoubtedly an agricultural vocation. Farming sector provides most of permanent and seasonal jobs [OUELMOUHOUB 2005]; it is characterized by a very wide variety of cultures (citrus fruits, pear trees, pomegranate trees, medlar trees, quince trees, sorghum, melon, watermelon, and other vegetable growing [SADOUNE 2012]. Industry, in the proper sense of the term, is almost nonexistent in the basin, as well as in the whole province [SAADALI et al. 2015]. It is mainly characterized by a few agri-food industry as a tomato canning factory, a lemonade factory and a bricks plant [BAHROUN 2016]. This wealth in the first two areas is currently a major concern, because these latter represent the most significant sources of pollution, namely: urban pollution represented by urban discharges in the study area, which are thrown up, without prior treatment, into the wadis. Domestic sewage contains mineral particles, faecal bacteria, organic matter, toxic products, significant quantities of nitrogen and phosphorus, as well as other products [GAUJOUS 1995]. Agricultural pollution is mainly related to the existence of several farms, practicing various types of cultures, the intensive use of fertilizers and pesticides rich in nitrate, phosphate and sulphate. These generate nitrogen-rich leachate (organic or ammoniacal nitrogen), which is conveyed by the runoff after spreading and joins surface waters by hypodermic flow [CANN 2000; RECOUS et al. 1995].

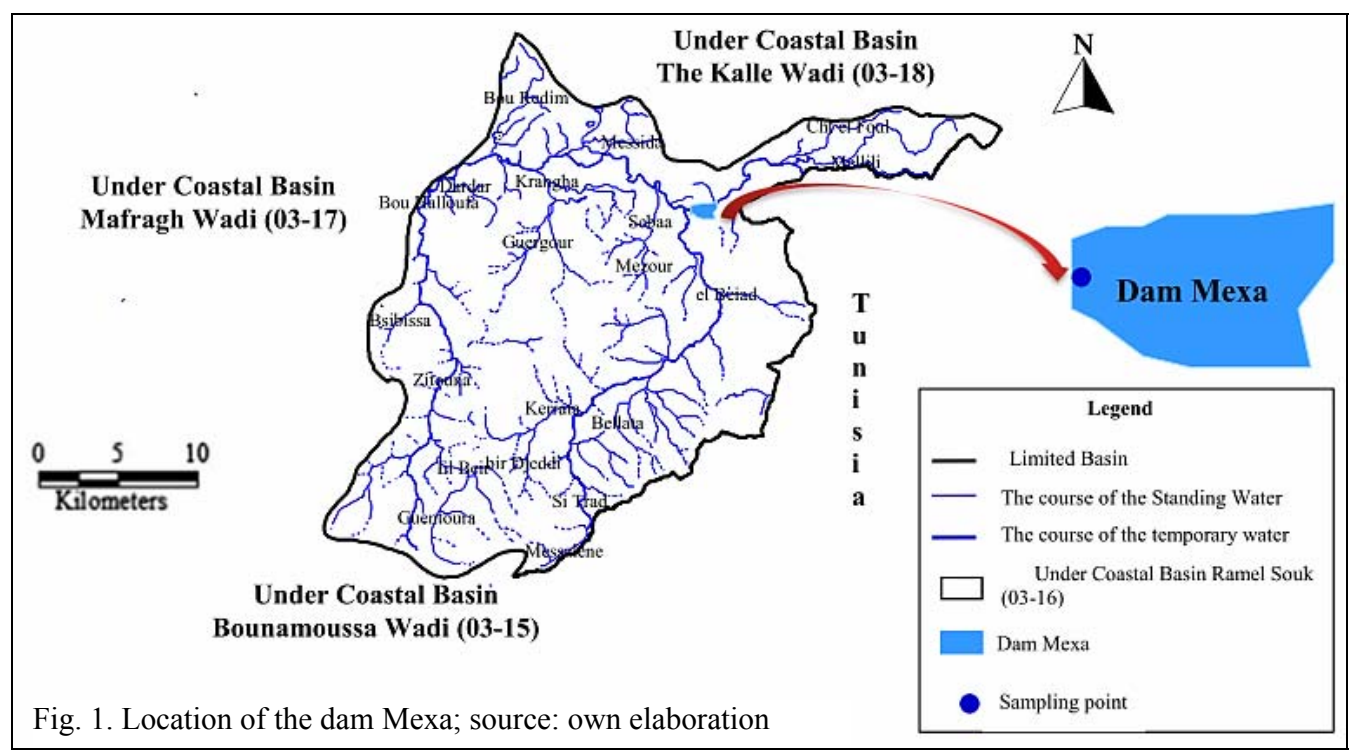




\section{MATERIALS AND METHODS}

The sampling of waters of the dam reservoir Mexa have been carried out for a period of three years (2010, 2011 and 2012), one sample per month. The sample has been taken on the raw water of the dam reservoir itself. In total, 36 water samples have been collected at the reservoir of the dam Mexa. The samples of surface water have been collected directly with polyethylene bottles. All sampling bottles have previously been washed with an alkaline solution and rinsed several times with distilled water.

The sampling can be performed in several ways according to the accessibility of the site, in our case, the ideal is to collect samples at outlet of the dam reservoir and at the middle; in the morning at 15 to 30 $\mathrm{cm}$ depth, and in a way to avoid the edge effects (oxygenation, too close to the surface, suspension of solid material too near the bottom), by facing water streams. This is what is called spot sampling [Agence de l'eau Loire 2003; Aqua-Ref 2011].

The samples were stored at a temperature of $4{ }^{\circ} \mathrm{C}$. The measurements of temperature, electrical conductivity, dissolved oxygen and $\mathrm{pH}$ have been carried out in the field using specific probes of a multi-parameter device. The chemical analyses have been conducted in the laboratory. The analyses of major elements have been performed on the previously filtered samples. Chlorides have been dosed by the method of Mohr, gravimetric sulphates and bicarbonates by the volumetric method. Sodium, potassium, calcium and magnesium ions have been dosed by means of flame spectrometer.

Nitrates, nitrites, phosphates and ammonium have been dosed by flame spectrophotometer [RODIER 2009]. The parameter of biological oxygen demand has been measured using an OxiTop IS12. In addition, the characterization of geochemical facies of surface water has been conducted using Piper diagram.

\section{RESULTS AND DISCUSSION}

\section{TEMPERATURE}

The temperature of water taken from the dam reservoir Mexa during the period of (2010-2012) varies between $10^{\circ} \mathrm{C}$ recorded in January 2012 and $30^{\circ} \mathrm{C}$ in August 2012, with an annual mean temperature of $19.05^{\circ} \mathrm{C}$. This state of temperature remains lower than that reported by MEHANNED et al. [2014] at the dam Sidi Chahed (Morocco). These variations are directly related to the temperature of air and seasons. The dam reservoir water has a normal temperature $\left(<25^{\circ} \mathrm{C}\right)$.

\section{HYDROGEN POTENTIAL}

The $\mathrm{pH}$ of water of the dam reservoir Mexa recorded on samples is rather alkaline and varies between 7.1 recorded in November 2011 and 8.4 in September 2010, with an average of around 7.67 reflect- ing a normal quality. These results are consistent with those found by HARRAT [2007] at the dam Mexa.

\section{ELECTRICAL CONDUCTIVITY}

The electrical conductivity of water of the dam reservoir Mexa measured during the period of (20102012) varies between 340 and $710 \mu \mathrm{S} \cdot \mathrm{cm}^{-1}$. The highest value is recorded in June 2011 and the lowest in March 2012, the average is of the order of 518.89 $\mu \mathrm{S} \cdot \mathrm{cm}^{-1} 90 \%$ of the values of electrical conductivity measured at the dam reservoir water exceed the maximum permissible standard of water for human consumption, referenced to the standard of $400 \mu \mathrm{S} \cdot \mathrm{cm}^{-1}$. This increase indicates contamination of water and makes it unsuitable for human consumption. It should also be noted that the highest values have been recorded during the low-water period while in the highwater period a phenomenon of dilution appears. As compared to other works, the conductivity is lower than that reported by ISMAIL et al. [2010] at the dam Bir M'chergua (Tunisia).

\section{TURBIDITY}

According to the results of the series of analyses of water of the dam reservoir Mexa, we have noted that the water sample of May 2011 is the most turbid (it has a turbidity of 100 NTU). This is explained by the presence of colloidal particles in suspension of clay and various organic matter (as a result of urban discharges). The lowest is of the order of $1.4 \mathrm{NTU}$ recorded during January 2011. In general, the mean turbidity is of 15.65 NTU reflecting from good to fair quality. The results are comparable to those obtained by HARRAT [2007] at the dam Mexa.

\section{DISSOLVED OXYGEN}

The values obtained for dissolved oxygen ranging from $5.7 \mathrm{mg} \cdot \mathrm{dm}^{-3}$ in January 2012 to $11.2 \mathrm{mg} \cdot \mathrm{dm}^{-3}$ in February and December 2011. The mean is of 8.62 $\mathrm{mg} \cdot \mathrm{dm}^{-3}$ reflecting normal quality. The results are comparable to those obtained by ISMAIL et al. [2010] at the dam Bir M'chergua (Tunisia).

\section{MAJOR ELEMENTS}

The results of analyses of major elements (sulphate, chloride, calcium, magnesium, sodium, potassium and bicarbonate) corresponding to water of the dam reservoir Mexa are presented as follows.

Sulphates. The concentrations observed in water of the dam reservoir basin indicate that the mean contents of sulphate do not exceed the standard. The maximum value is of $120 \mathrm{mg} \cdot \mathrm{dm}^{-3}$ recorded in January 2010 while the lowest is $80 \mathrm{mg} \cdot \mathrm{dm}^{-3}$ recorded during December 2012. The mean is of $80.89 \mathrm{mg} \cdot \mathrm{dm}^{-}$ ${ }^{3}$. The concentrations of our waters are still higher than those reported by CHAHBOUNE et al. [2013] at 
the dam reservoir Hassan II (Morocco). The origin of water sulphates is Pliocene-Quaternary alluvia [HANDOUZI 2011].

Chlorides. It is noted that chloride levels in water of the dam reservoir Mexa do not exceed the World Health Organization standard $\left(250 \mathrm{mg} \cdot \mathrm{dm}^{-3}\right)$. The maximum concentration is of $70 \mathrm{mg} \cdot \mathrm{dm}^{-3}$ recorded in August 2011 while the lowest value is of $30 \mathrm{mg} \cdot \mathrm{dm}^{-3}$ recorded in April 2010; the mean value of chlorides in water of the dam reservoir is about $51.11 \mathrm{mg} \cdot \mathrm{dm}^{-3}$. These results are consistent with those found by Chahboune et al. [2013] at the dam reservoir Hassan II (Morocco). Water chlorides are from Numidian clays, and marls and clayey marls are from Lutetian [BAHROUN 2016].

Calcium. Water of the dam Mexa has calcium levels between a minimum value of $40.6 \mathrm{mg} \cdot \mathrm{dm}^{-3}$ observed on May 2012 and a maximum value of 86.3 $\mathrm{mg} \cdot \mathrm{dm}^{-3}$ recorded in June 2011, with a mean of 62.27 $\mathrm{mg} \cdot \mathrm{dm}^{-3}$. Calcium content in water of the dam reservoir is consistent with the maximum permissible standard of water intended for human consumption (classified as good quality). As compared to other works, the concentrations are lower than those reported by ISMAIL et al. [2010] at the dam reservoir Bir M'chergua (Tunisia).

Magnesium. The highest levels are observed on September 2010, with a maximum value of 23 $\mathrm{mg} \cdot \mathrm{dm}^{-3}$. The lowest value is recorded in December 2012. The dam reservoir water reaches a magnesium mean value of about $12.22 \mathrm{mg} \cdot \mathrm{dm}^{-3}$. The comparison of concentrations with the permissible standard for potability shows that the levels are below the limit. These results are not consistent with those found by ISMAIL et al. [2010] at the dam Bir M'chergua (Tunisia), because they are less high.

Sodium. Sodium values fluctuate between 10 $\mathrm{mg} \cdot \mathrm{dm}^{-3}$ in June 2012 and $39 \mathrm{mg} \cdot \mathrm{dm}^{-3}$ in December 2011; the mean is of the order of $27.92 \mathrm{mg} \cdot \mathrm{dm}^{-3}$, lower than the permissible European standard (100 $\mathrm{mg} \cdot \mathrm{dm}^{-3}$ ), and does not reach the Algerian standard of $200 \mathrm{mg} \cdot \mathrm{dm}^{-3}$. The results are comparable to those obtained by HARRAT [2007] at the dam Mexa, Cheffia and Beni Zid (Algeria).

Potassium. The highest potassium values are of the order of $3 \mathrm{mg} \cdot \mathrm{dm}^{-3}$, and the lower values are of the order of $1 \mathrm{mg} \cdot \mathrm{dm}^{-3}$ observed during the three years. The mean is of the order of $1.78 \mathrm{mg} \cdot \mathrm{dm}^{-3}$, lower than the potability standard of the World Health Organization $\left(12 \mathrm{mg} \cdot \mathrm{dm}^{-3}\right)$ and the Algerian standard $\left(20 \mathrm{mg} \cdot \mathrm{dm}^{-3}\right)$. The results are comparable to those obtained by HARRAT [2007] at the dam Mexa, Cheffia and Beni Zid (Algeria).

Bicarbonates. The maximum concentrations of bicarbonates in water of the dam reservoir basin are of the order of $201.3 \mathrm{mg} \cdot \mathrm{dm}^{-3}$ recorded in June 2011, and the minimum is of the order of $85.5 \mathrm{mg} \cdot \mathrm{dm}^{-3} \mathrm{re}-$ corded in March 2010. The concentrations show significant variations around the mean value of 134.78 $\mathrm{mg} \cdot \mathrm{dm}^{-3}$, indicating heterogeneity of bicarbonate ori- gins. Our bicarbonate contents remain lower than those reported by ISMAIL et al. [2010] at the dam Bir M'chergua (Tunisia).

\section{GEOCHEMICAL FACIES OF WATER}

Classification according to Piper diagram. The results of the chemical analyses of the dam reservoir water for the three years and during all the sampling months (from January to December) are shown in Piper diagram below (Fig. 2). This figure shows that the dominance of bicarbonate ions is clear on sulphates and chlorides.

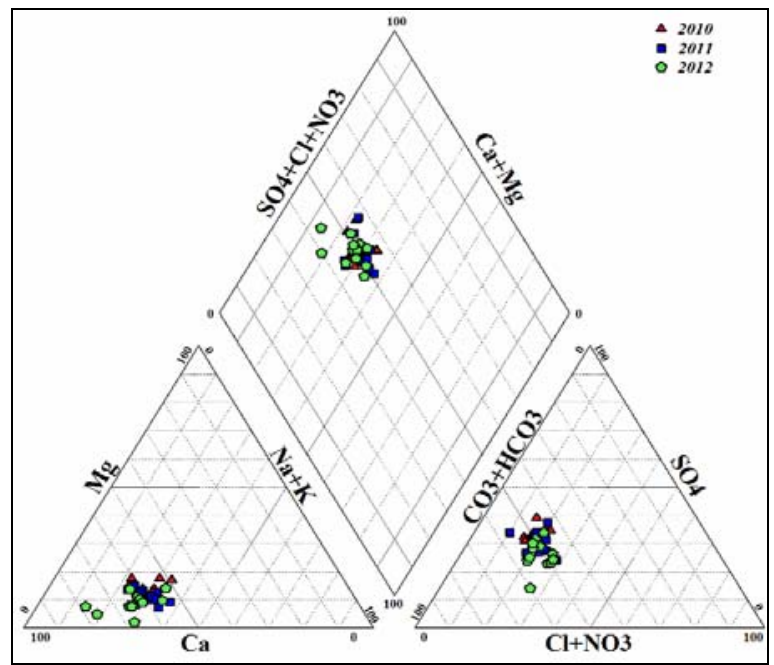

Fig. 2. Piper diagram of water chemistry in Mexa dam reservoir for the period 2010-2012; source: own study

The interpretation of diagram (Fig. 2) has allowed us to highlight a clear concentration of points cloud located on the upper and left parts. It therefore shows an enrichment of bicarbonate and calcium, a dominant facies grouping bicarbonate-calcium family. It has to be noted that calcium cations characterize the totality of the points represented on cations triangle, giving indications on the origin of water. Bicarbonate anions characterise all the points represented on anions triangle, giving indications on the origin of water.

Alteration of water of the dam reservoir Mexa and pollution indicator element. In order to assess the water quality of the studied dam reservoir, we refer to the grid of the overall quality of surface water of dams in Algeria, according to National Agency of Water Resources [ABHCSM 2005] (Tab. 1).

\section{BIOLOGICAL OXYGEN DEMAND}

In fact, the time profile of biological oxygen demand (Fig. 3) shows the presence of an organic load during 2011 and 2012. These values can reach $7 \mathrm{mg} \cdot \mathrm{dm}^{-3}$.

During 2010, the percentage of samples displaying an excellent quality is of $41.66 \%$, this percentage increases to $75 \%$ in 2011 and decreases to $33.33 \%$ 
Table 1. Quality grid of the surface waters

\begin{tabular}{|c|c|c|c|c|c|}
\hline \multirow[b]{2}{*}{ Parameter } & \multicolumn{5}{|c|}{ Quality class } \\
\hline & excellent & good & fair & poor & $\begin{array}{l}\text { excessive } \\
\text { pollution }\end{array}$ \\
\hline \multicolumn{6}{|c|}{ Organic and oxidizable matter } \\
\hline $\mathrm{OM}, \mathrm{mg} \cdot \mathrm{dm}^{-3}$ & $<3$ & $3-5$ & $5-8$ & $8-10$ & $>10$ \\
\hline $\mathrm{COD}, \mathrm{mg} \cdot \mathrm{dm}^{-3}$ & $<20$ & $20-30$ & $30-40$ & $40-80$ & $>80$ \\
\hline $\mathrm{BOD}_{5}, \mathrm{mg} \cdot \mathrm{dm}^{-3}$ & $<3$ & $3-6$ & $6-10$ & $10-25$ & $>25$ \\
\hline \multicolumn{6}{|c|}{ Dissolved oxygen } \\
\hline $\mathrm{O}_{2}, \%$ & $>90$ & $90-70$ & $70-50$ & $50-30$ & $<30$ \\
\hline \multicolumn{6}{|c|}{ Nitrogenous matter } \\
\hline $\mathrm{NH}_{4}^{+}, \mathrm{mg} \cdot \mathrm{dm}^{-3}$ & $<0.1$ & $0.1-0.5$ & $0.5-2$ & $2-5$ & $>5$ \\
\hline $\mathrm{NO}_{2}^{-}, \mathrm{mg} \cdot \mathrm{dm}^{-3}$ & $<0.03$ & $0.03-0.1$ & $0.1-0.5$ & $0,5-1$ & $>1$ \\
\hline \multicolumn{6}{|c|}{ Nitrates } \\
\hline $\mathrm{NO}_{3}^{-}, \mathrm{mg} \cdot \mathrm{dm}^{-3}$ & $<2$ & $2-10$ & $10-25$ & $25-50$ & $>50$ \\
\hline \multicolumn{6}{|c|}{ Phosphorus matter } \\
\hline $\mathrm{PO}_{4}^{-3}, \mathrm{mg} \cdot \mathrm{dm}^{-3}$ & $<0.1$ & $0.1-0.5$ & $0,5-1$ & $1-2$ & $>2$ \\
\hline \multicolumn{6}{|c|}{ Electrical conductivity } \\
\hline$E C, \mu \mathrm{S} \cdot \mathrm{cm}^{-1}$ & $<2500$ & $\begin{array}{c}2500- \\
3000 \\
\end{array}$ & $\begin{array}{c}3000- \\
3500 \\
\end{array}$ & $\begin{array}{c}3500- \\
4000\end{array}$ & $>4000$ \\
\hline \multicolumn{6}{|c|}{ Turbidity } \\
\hline Turbidity, NTU & $<2$ & $2-35$ & $35-70$ & $70-105$ & $>105$ \\
\hline
\end{tabular}

Source: own study.

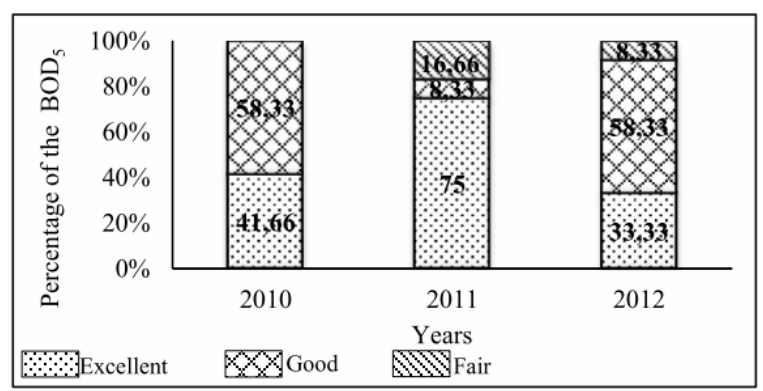

Fig. 3. Temporal variability of the biological oxygen demand; source: own study

during the year 2010, this decrease is due to the existence of an organic load of which $8.33 \%$ of the samples display a fair quality. During the year 2010, $58.33 \%$ of the samples exhibit a good quality, this percentage decreases to $8.33 \%$ during 2011 , this is explained by the presence of organic load of which $16.66 \%$ of the samples exhibit a fair quality. For the year 2012, the percentage of samples exhibiting a good quality increases to $58.33 \%$. From these histograms, we note that there is a deterioration of water quality during the years 2011 and 2012.

\section{CHEMICAL OXYGEN DEMAND}

On the whole, and from the Figure 4, it is observed that the percentage of high-quality samples for chemical oxygen demand decreases from one year to another, with values ranging from $41.66 \%$ in 2010 to $0 \%$ during 2012. The same observation of samples displaying a good quality; the percentage is of $50 \%$ in 2010 and decreases to $16.66 \%$ in 2011 to reach $0 \%$ in the year 2012 .

The percentage of samples of fair quality increases from $8.33 \%$ in 2010 to $33.33 \%$ in 2011 to reach $58.33 \%$ in 2012 . The samples of poor quality are of

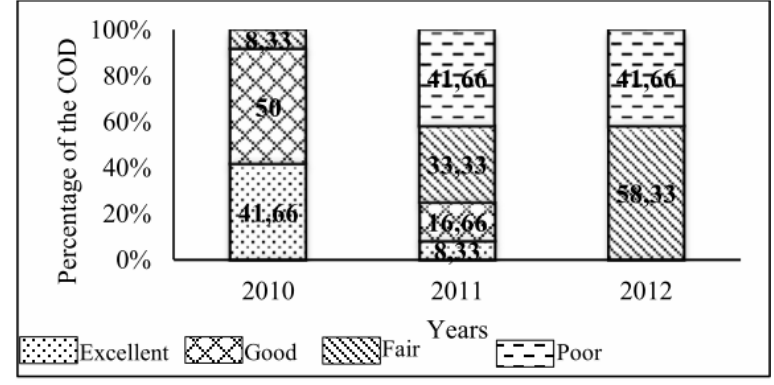

Fig. 4. Temporal variability of chemical oxygen demand; source: own study

the order of $41.66 \%$, this percentage remains stable during the years 2011 and 2012. The histograms show a significant deterioration of the quality of the dam reservoir water during the year 2012 .

\section{ORGANIC MATTER}

The analysis results show that $16.66 \%$ of samples show a good quality of organic matter, this percentage remains stable during the years 2010 and 2011. The percentage of samples of fair quality is of $75 \%$ for the year 2010 and decreases to $58.33 \%$ for the year 2011, this decrease is due to the degradation of water quality of which $16.66 \%$ of samples are of poor quality, and $8.33 \%$ show an excessive pollution (Fig. 5).

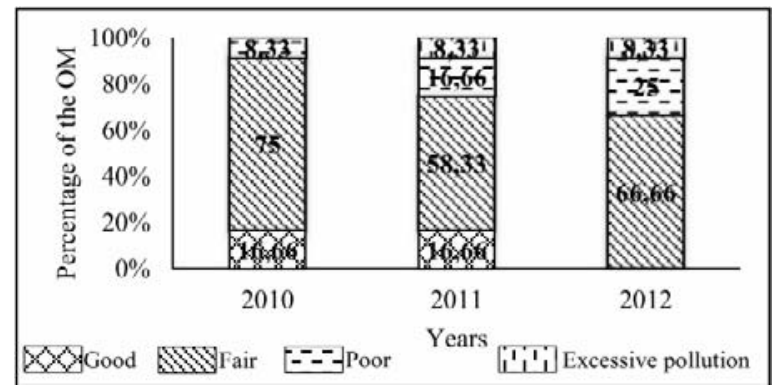

Fig. 5. Temporal variability of organic matter; source: own study

During the year 2012, the deterioration of the quality of water of the reservoir of the dam Mexa becomes more important whose percentage of fair and poor quality increases respectively to $66.66 \%$ and $25 \%$. In contrast, the percentage of pollution levels out $8.33 \%$.

\section{NITRITES}

The percentage of samples whose water show a natural composition of nitrites is of $33.33 \%$ for the year 2010 and $16.66 \%$ for the year 2012, and increases to $50 \%$ for the year 2011 ; this is explained by the decrease of samples whose water is degraded significantly to $8.33 \%$ (Fig. 6).

As regards the good quality, the percentage levels out, the significantly quality deterioration is of $16.66 \%$ in 2010 and decreases to $8.33 \%$ in 2011 , this deterioration increases to $33.33 \%$ in 2012 , and this is 


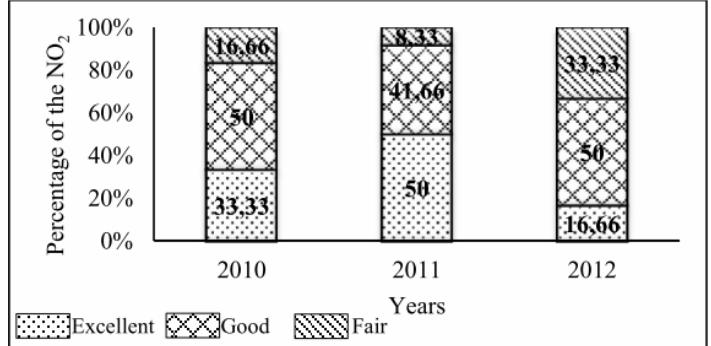

Fig. 6. Temporal variability of nitrites; source: own study

due to the decrease of water percentages showing an excellent quality with respect to the natural state.

\section{NITRATES}

The percentage of samples with excellent quality nitrates is of $41.66 \%$ in 2010 ; the percentage decreases to $25 \%$ and remains stable during 2011 and 2012. The decrease in 2011 is due to the significant and serious deterioration of water of the dam reservoir Mexa, which is of $8.33 \%$ for both levels (Fig. 7).

The good quality of water remains stable at $58.33 \%$ during 2010 and 2011 and increases to $75 \%$ in 2012. This increase is due to the reduction of samples whose water is of a very good quality.

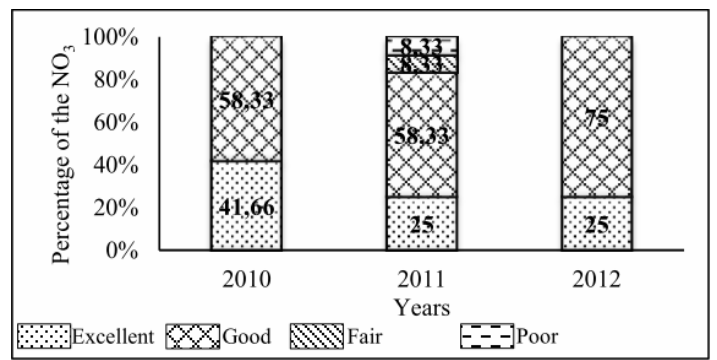

Fig. 7. Temporal variability of nitrates; source: own study

\section{PHOSPHATE}

The percentage of samples, whose water is of a very high phosphate quality, increases in 2012 to $41.66 \%$ instead of $16.66 \%$ in 2010 and 2011 (Fig. 8). This is explained for the year 2012 by the increase in the percentage of good water to $75 \%$ for the years 2010 and 2011 and by the increase in the percentage of water of good quality while the significant degradation is on the water whose percentage is of $8.33 \%$.

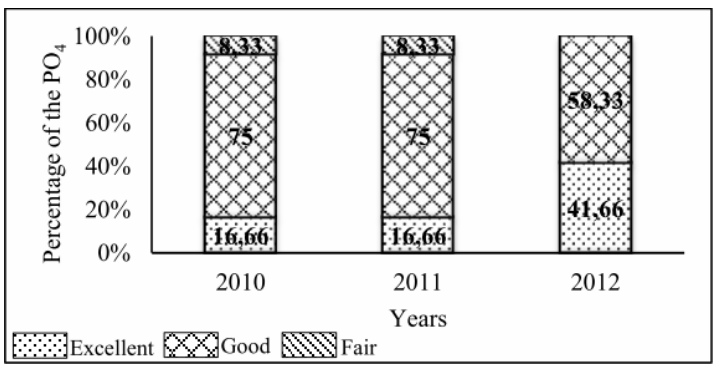

Fig. 8. Temporal variability of phosphate; source: own study

\section{AMMONIUM}

According to Figure 9, it is observed that the quality of water of the dam reservoir Mexa has improved for ammonium quality during the period $2010 / 2012$; this is explained by the increase in the percentage of samples with very good quality water. The percentage is $75 \%$ in 2010 and passes to $83.33 \%$ in 2011 to reach $91.66 \%$ in 2012 , and concerning the decrease in the percentage of samples whose water shows a good quality, the percentage is of $25 \%$ in 2010 and decreases to $16.66 \%$ in 2011 to reach $8.33 \%$ in 2012.

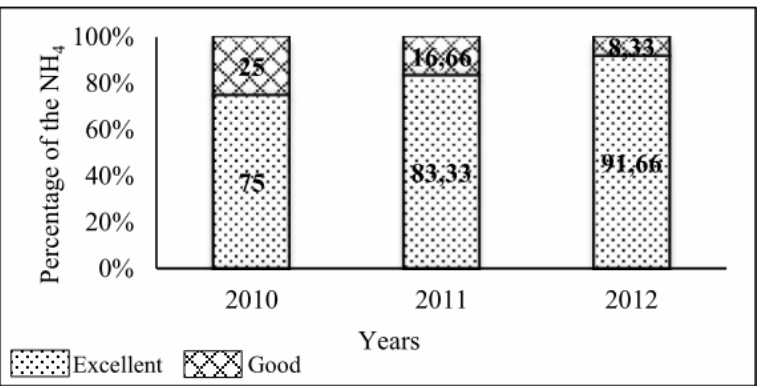

Fig. 9. Temporal variability of ammonium; source: own study

\section{TURBIDITY}

The percentage of samples showing a good quality of turbidity is of $100 \%$ in 2010 and decreases to $50 \%$ in 2011 , due to the increase of the percentage of water showing a very good quality on the one hand, and showing significant and substantial degradation of $8.33 \%$ of samples on the other hand. In 2012, the quality improves by the increase of the percentage of good quality water to $83.33 \%$, but from the point of view, significant and substantial degradation, the percentage remains stable $8.33 \%$ (Fig. 10).

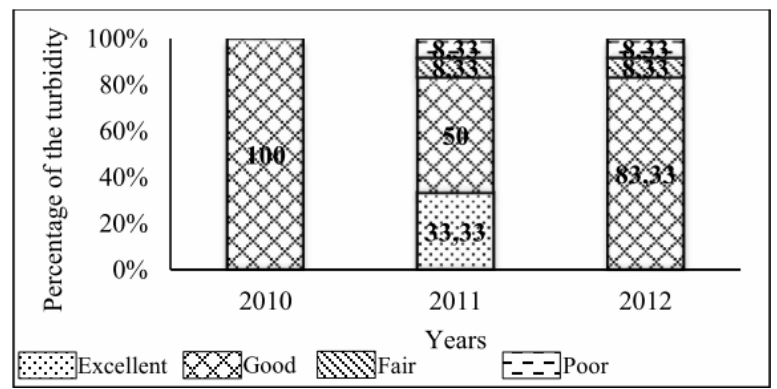

Fig. 10. Temporal variability of turbidity; source: own study

\section{SATURATION}

According to the histograms on Figurer 11, we observe that the water quality is very good to good in 2010 , with a percentage of $50 \%$. In 2011 , the quality improves due to an increase in the percentage of water with excellent quality and a decrease in the percentage of water with good quality. 


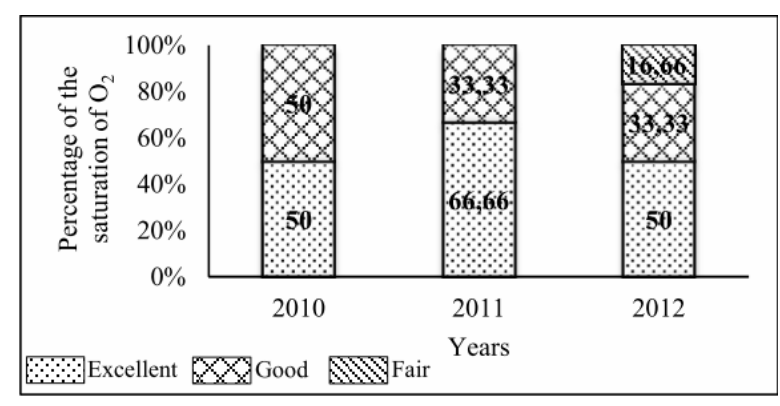

Fig. 11. Temporal variability of the saturation; source: own study

In 2012, the quality deteriorates; this is explained by the decrease in the percentage of water showing a very good quality of $50 \%$ and the increase in the percentage of water showing a significant degradation of $16.66 \%$.

\section{ELECTRICAL CONDUCTIVITY}

The quality of the dam reservoir water is stable for the electrical conductivity during the period 2010 2012 (Fig. 12), all water samples are of a very good quality compared to the natural state, whose percentage of waters of excellent quality is of $100 \%$ and remains stable during the years 2010, 2011 and 2012.

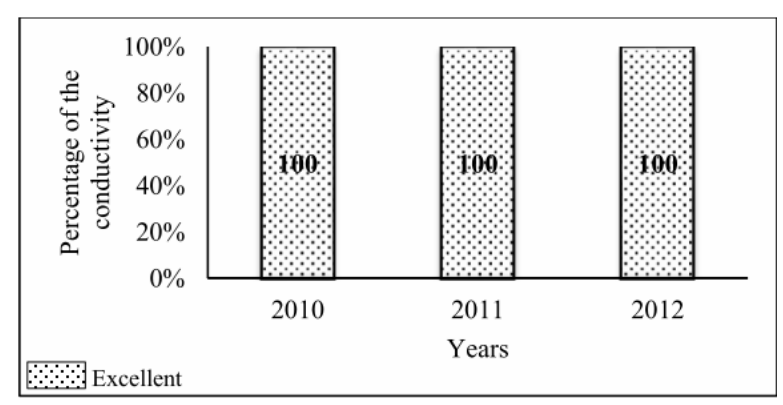

Fig. 12. Temporal variability of electrical conductivity; source: own study

The water quality is a factor and a result at the same time, the first role appears when the physicochemical characteristics of water determine the vulnerability of ecosystems to destructive effects.

According to our analysis and according to the indicator parameters of the quality of raw water of the dam reservoir Mexa, water reveals an excellent conductivity during the years 2010, 2011 and 2012 (Fig. 13). These results are comparable to those obtained by Agency Hydrographic Basin (Fr. Agence de Bassin Hydrographique), 2005 at the dam Mexa and Guenitra (Algeria). For turbidity, low turbidity is observed during 2010, and high turbidity is revealed during the years 2011 and 2012 where the contribution of runoff increases water turbidity. The rainwater carries the particles during their flow and increases this latter. The quality is worse than that obtained by Agency Hydrographic Basin [ABHCSM 2005] at the reservoir dams Mexa and Guenitra (Algeria).

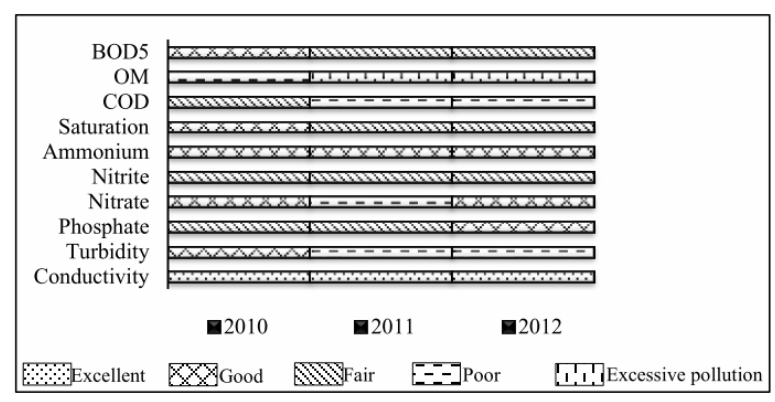

Fig. 13. Water quality of the dam Mexa during the period 2010/2012; source: own study

The comparison of the water quality indices of the dam reservoir Mexa during the three years of study (2010, 2011 and 2012) shows a somewhat pessimistic diagnosis. In fact, the results gathered in Figure 13 establish clearly the unfitness of all samples for drinking water supply and require a complete treatment due to significant alteration for almost all the parameters during the years 2011 and 2012.

From this figure, it is observed that water of the dam reservoir Mexa contains more oxidisable and nitrogen organic matter, such as nitrites that clearly indicate a gradual degradation of water quality throughout the years marked by organic pollution. This critical state of water is explained by very high levels of nitrite, phosphate, biological oxygen demand, chemical oxygen demand and organic matter. The quality is comparable to that obtained by Agency Hydrographic Basin, 2005 at the dam Guenitra (Algeria), but worse than that reported by Agency Hydrographic Basin [ABHCSM 2005] at the dam Mexa. The evolution of values shows that this degraded state of water quality of the dam reservoir is due to the discharges of domestic wastewater from agglomerations, as well as to agricultural leaching.

\section{CONCLUSION}

At the end of this study, the results obtained for the state of the quality of the waters of the dam reservoir Mexa seem to highlight the direct impact of the overall pollution, generated by the discharge of wastewater of the locality of El-Taref. In fact, this physicochemical quality of water of the dam reservoir reveals that waters are weakly mineralized $(E C$ $1000 \mu \mathrm{S} \cdot \mathrm{cm}^{-1}$ ) and neutral. In the region, waters exhibit a bicarbonate-calcium facies. The chemical parameters of quality are all below the standard of potability WHO. Significant pollution confirmed by high values of biological oxygen demand, chemical oxygen demand, organic matter, phosphate and nitrite. This pollution could be accentuated by the leaching of salts concentrated at the surface of agricultural soils treated by fertilizers, and also by the domestic discharges from the homes settling throughout the two shores of the wadis. The comparison with earlier work done toward the end of the years 2003 [ABHCSM 2005] has revealed that the dam reservoir waters, which 
generally exhibit a medium organic quality, undergo today an important degradation during the year 2011 and become very important in 2012. This study has highlighted the risk to which is exposed human population, which consumes water of the dam reservoir Mexa. Therefore, this study will probably have to be followed by other complementary studies that will be financed by the authorities to protect health of the populations from the toxicity of pollutants and to preserve water of wadis and of the dam reservoir from any kind of pollution. It seems essential to stop this pollution by taking necessary steps. The restoration of this dam, which is fed by Wadi Kebir, requires a renovation plan resting on the location of the sanitation system that link sewage to the main sewers, or the construction of canals along the shores of wadis supplying the dam reservoir to group all the waters thrown up, canals can convey them downstream, to purification plants, which will be set up. To limit diffuse pollution of agricultural origin, farmers must take a lot of precautions when using pesticides and insecticides, and must respect the dose of fertilizers and the storage conditions of their manure.

\section{REFERENCES}

ABHCSM 2005. Qualité des eaux superficielles dans le bassin hydrographique Constantinois-Seybousse, Mellegue 1998-2003 [Quality of surface water in the Constantinois-Seybousse watershed, Mellegue 19982003]. Constantine. Agence de Bassin Hydrographique Constantinois-Seybousse-Mellegue pp. 25.

ACHOUR S. 2001. Incidence des procédés de chloration, de floculation et d'adsorption sur l'évolution de composés organiques et minéraux des eaux naturelles [Effect of chlorination, flocculation and adsorption processes on the evolution of organic and mineral compounds in natural waters]. PhD thesis. Hydraulic Sciences. University of Tizi-Ouzou, Algeria pp. 231.

Agence de l'eau Loire 2003. Le prélèvement d'échantillon en rivière. Techniques d'échantillonnage en vue d'analyse physicochimiques, guide technique [Sample collection in river. Sampling techniques for physicochemical analysis, technical guide]. Bretagne. ISBN 978-2-916869-00-1 pp. 60.

Allalgua A., Ayari AT., Boutmedjet S., Znati N., Kaouachi N., Boualleg C., Boucenna I., Bensouilah M. 2014. Caractérisation physico-chimique et bactériologiques des eaux brute et potables du Barrage Ain Dalia (Souk-Ahras) Caractérisation physico-chimique et bactériologiques des eaux brute et potables du Barrage Ain Dalia (Souk-Ahras). [Physico-chemical and bacteriological characterization of the raw and drinking waters of the Dam Ain Dalia (Souk-Ahras). 1st National Seminar on Health and Bio-Surveillance of Aquatic Ecosystems]. University of Souk Ahras, Algeria pp. 8.

Aqua-Ref 2011. Guide des prescriptions techniques pour la surveillance physicochimique des milieux aquatiques: opération d'échantillonnage en cours d'eau (eaux et sédiments) en milieu continental [Guide to technical prescriptions for the physico-chemical monitoring of aquatic environments: Sampling in watercourses (waters and sediments) in continental environments] pp. 32 .
Attoui B., Toumi N., Messaouidi S., Benrabah S. 2016. Degradation of water quality: The case of plain west of Annaba (northeast Algeria). Journal of Water and Land Development. No. 31 p. 3-10. DOI 10.1515/jwld-20160031.

BAHROUN S. 2016. Objectifs environnementaux de rejet pour les polluants dans le milieu récepteur et optimisation du pouvoir auto-épurateur: cas de l'oued Kébir Est (nord est algérien) [Environmental rejection objectives for pollutants in the receiving environment and optimization of self-purifying power: Case of Wadi Kébir Est (northeast Algeria)]. PhD thesis. Faculty of Earth Sciences, University of Annaba, Algeria pp. 220.

Bahroun S., Bousnoubra H., Drouiche N., KHerici N. 2016. Analysis of wastewater discharges to the Wadi Kebir East River by the environmental discharge objectives (EDO) method. Desalination and Water Treatment. Vol. 57. Iss. 52 p. $24750-24754$.

Brahamia K., Semouk A. 2010. Activité touristique dans un espace fragile: cas du parc national d'El Kala [Tourism activity in a fragile space: Case of El Kala National Park]. El-Tawassol. No. 26 p. 34-57.

CANN A.J. 2000. Virus culture - A practical approach. The Practical Approach Series. No. 208. Oxford University Press pp. 296.

Chahboune E.M., Chahlaoui A., Zaid A., Ben Moussa A. 2013. Contribution à la caractérisation physicochimique des eaux du lac réservoir du barrage Hassan II [Contribution to the physicochemical characterization of reservoir waters of Lake Hassan II dam]. Larhyss Journal. No. 14 p. 61-77.

Derdous O., Djemili L., Bouchehed H., Tachi S.E. 2015. A GIS based approach for the prediction of the dam break flood hazard - A case study of Zardezas reservoir "Skikda, Algeria". Journal of Water and Land Development. No. 27 p. 15-20. DOI 10.1515/jwld-20150020.

Derradji E.F., Kerici N., Romeo M., Caruba R. 2007. Impact de la pollution organique des eaux superficielles dans le Nord-Est Algérien [Impact of organic pollution of surface waters in the northeastern Algeria]. Secheresse. Vol. 18 p. 23-25.

GARCiA A. 2006. Etude de la dynamique des Escherichia coli dans les rivières du bassin de la Seine [Study of the dynamics of Escherichia coli in the rivers of the Seine basin]. PhD thesis. University of Brussels p. 15-16.

Gaujous D. 1995. La pollution des milieux aquatiques: Aide-mémoire [Pollution of aquatic environments: Checklist]. $2^{\text {nd }}$ ed. Technical Publishing and Documentation Lavoisier pp. 220.

HANDOUZI M. 2011. Evolution du chimisme des eaux du barrage Mexanna (Nord-Est Algérien) [Evolution of chemistry of the waters dam Mexanna (northeast Algeria)]. MSc thesis. Faculty of Earth Sciences, University of Annaba pp. 103.

Harrat N. 2007. Qualité des eaux de surface de l'Est algérien et leur réactivité vis-à-vis du chlore [The quality of surface waters in eastern Algeria and their reactivity to chlorine]. MSc thesis. IST, University of Annaba pp. 62.

HARRAt N., ACHOuR S. 2010. Pollution physico-chimique des eaux de barrage de la region d'el Tarf. Impact sur la chloration [physico-chemical pollution of dams waters in the el Tarf region. Impact on chloration]. Larhyss Journal. No. 08 p. 47-54.

Ismail Y., Benalaya A., Mchabet M. 2010. Caractérisation Physicochimique des Eaux du Barrage Bir 
M'chergua et de ses Affluents (Tunisie) [Physico chemical Characterization of Waters of dam Bir M'chergua its Affluents (Tunisia)]. V International Congress on Renewable Energies and the Environment. Sousse, Tunisia pp. 10.

Mehanned S., Chahlaoui A., Zaid A., Samin M., ChaHBOUNE M. 2014. Typologie de la qualité physicochimique de l'eau du barrage Sidi Chahed-Maroc [Typology of the physic-chemical quality of the waters of the dam Sidi Chahed-Morocco]. Journal of Materials and Environmental Science. Vol. 5. No. 2 p. 16331642.

Ministère de Ressources en Eau 2009. Étude d'inventaire de développement de la PMH, Wilaya El Tarf, Partie $\mathrm{N}^{\circ} 1$. 2340074 [Directorate of Agricultural Water, Study Inventory Development of PMH, El Tarf Wilaya. Part 1 No. 234 0074] pp. 50.

Ouelmouhoub S. 2005. Gestion multi-usage et conservation du patrimoine forestier: cas des subéraies du Parc National d'El Kala (Algérie) [Multi-use management and conservation of the forest heritage: Case of the subaeryes of El Kala National Park (Algeria)]. Thesis of science CIHEAM-IAM Montpellier, France. No. 78 p. $46-54$.

Recous S., RoBIN D., DARwis D., MARY B. 1995. Soil inorganic $\mathrm{N}$ availability: Effect on maize residue decomposition. Soil Biology and Biochemistry. Vol. 27. Iss. 12 p. $1529-1538$.
Remini B. 2010. La problématique de l'eau en Algérie du nord [The problem of water in northern Algeria]. Department of Water and Environmental Sciences. Larhyss Journal. No. 08 p. 27-46.

RODIER J. 2009. L'analyse de l'eau, eaux naturelles, eaux résiduaires et eau de mer [Analysis of the water natural water, waste water, sea water]. Ninth ed Dunod, Paris, France pp. 1579.

SAADAli B., DeRRAdjI E.F., SABoua T., REMita R., ZAhi F. 2015. Impact de l'activité anthropique sur la dégradation de l'environnement et sur la qualité des eaux: Cas du parc national d'El Kala (Nord - Est Algérien) [Impact of the anthropogenic activity on the degradation of the environment and water's quality: El Kala National Park (NorthEast of Algeria)]. Synthesis of Science and Technology. Vol. 30. No. 1 p. 66-75.

SAdoune A. 2012. Vulnérabilité, et évaluation des ressources en eau dans l'extrême Nord-Est algérien [Vulnerability and assessment of water resources in the extreme northeast of Algeria]. MSc thesis. Faculty of Earth Sciences, University of Annaba pp. 99.

VILLA J.M. 1980. La chaine alpine d'algérie orientale et des confins algéro-tuunisiens [The Alpine chain Eastern borders Algeria Algerian-Tunisiens]. $\mathrm{PhD}$ thesis of natural sciences. Pierre and Marie Curie Paris 1 VI University pp. 665.

\section{Sofia BAHROUN, Warda CHAIB}

\section{Jakość wód powierzchniowych w zbiorniku zaporowym Mexa w północnowschodniej Algierii}

\section{STRESZCZENIE}

Przeprowadzono badania fizyczne i chemiczne, aby ocenić wpływ rolnictwa i miejskich ścieków bytowych na jakość wody w zbiorniku zaporowym Mexa w regionie El-Taref usytuowanym we wschodniej części basenu Constantine. Próby do analiz pobierano co miesiąc w ciągu trzech lat (2010-2012), łącznie 36 prób. W terenie mierzono temperaturę, $\mathrm{pH}$, przewodnictwo elektrolityczne i stężenie rozpuszczonego tlenu. W laboratorium analizowano aniony, kationy, biochemiczne zapotrzebowanie nas tlen, chemiczne zapotrzebowanie na tlen, stężenie fosforanów, azotanów III i V oraz jonów amonowych.

Stężenie różnych organicznych i nieorganicznych zanieczyszczeń zmieniało się w poszczególnych miesiącach i latach badań. Zanieczyszczenia wód zbiornika zaporowego Mexa zmieniały się w czasie w zależności od czynników klimatycznych. Stężenie zanieczyszczeń było małe w okresie zimowym i duże w okresach niskich przepływów. Uzyskane wyniki dowodzą, że wody zbiornika zaporowego Mexa są w znacznym stopniu zanieczyszczone, a zbiornik podlega zanieczyszczeniom pochodzącym z rolnictwa i ścieków miejskich.

Słowa kluczowe: jakość wody, zanieczyszczenie, zbiornik zaporowy Mexa, zwiazki organiczne 